\title{
SOCIAL CONFLICTS IN COASTAL TOURISTIC CITIES. HOLISTIC RENOVATION OF BUILDINGS IN BENIDORM
}

\author{
V. ECHARRI \& M. MAS \\ Department of Building Construction. University of Alicante.
}

\begin{abstract}
Mediterranean Touristic populated areas in the 70s pose great disadvantages when it comes to renovating. The transformation of such tourist resorts into permanent residence implies problems derived from the lack of design flexibility, excess of regulation and environmental issues. These holiday apartments, due to their dimensions and current conditions, are quite economical within the current housing market. However, the problems mentioned above can be seen when one has a close look at the high energetic consumption, the small dimension of the inhabited places, the lack of security against fire and the low level of hygrothermal comfort.

Benidorm underwent a large development in the 70s. As many other coastal Mediterranean cities, it has problems in providing its citizens and tourists with their needs. Many conflicts arise from sharing a common space, like the ones abovementioned. It is also worth mentioning that inhabited flats and houses have originated several social problems.

This paper intends to show a holistic strategy of intervention in a specific building that can also be implemented in other blocks of flats. This intervention is meant to redistribute the building both internally and externally, so the useful floor area is increased. Security in case of fire is solved by adding a second staircase, with two evacuation routes. There will also be a renovation with a new structural framework that will give a better climatic regulation function, and thus better energy efficiency. Besides, action will be taken over the resort gardens to produce a sustainable building outlook. In this way, there will be an improvement in the quality of life of the permanent employees working for the big number of tourists in this city.

Keywords: cultural heritage, landscape planning and design, quality of life, urban safety and security.
\end{abstract}

\section{INTRODUCTION}

In the 1960s and 70s, tourist development of the Spanish Mediterranean coastline led to an exponential growth in construction. The commercial rewards deriving from the demand for tourist accommodation meant that adequate town planning was needed. A lack of any established culture in this sector, together with aggressive speculation, led to inappropriate planning models. The need for service sector accommodation in urban centres led to the construction of poor quality housing. In many cases, the homes built were cramped and uncomfortable. The provision of educational and health facilities etc. were substandard compared to other population centres. With the passage of time and the social changes that came about in the 21st century, these buildings and the scant social facilities led to social conflicts. Urgent intervention is required in many of these areas in order to achieve balanced cities in terms of sustainable development [1].

This is the case with Benidorm, an urban centre representing the paradigm of tourist development in the province of Alicante. Some of the conservation irregularities and use of its buildings, despite the fact that the town continues to be successful tourist resort, are nothing 
short of surprising. According to the recent count carried out by the National Statistics Institute in 2013 on Census and Housing Population [2], the total housing stock in Benidorm amounts to 58,011 homes, of which $43.3 \%$ are seasonal dwellings. This amounts to 25,131 second homes. It is interesting to note that of the total housing stock available, $8.6 \%$ of homes were empty, a total of 4,988 dwellings. Some of these are the sole empty apartments in a building or they may account for the majority of the homes in others, where the entire edifice appears to have been abandoned. This contrasts with the decrease in numbers of empty homes in the last 10 years $-47.3 \%$ according to a study of the National Statistics Institute (INE), whereas growth in new first residences was $40 \%$. The problem resides in that $7.3 \%$ difference. There are 4,234 homes in the town, which were not destined as the main family residence but which were used during the summer season as holiday homes. These homes are now used to house poor families or those with no financial resources on a permanent basis, as a result of the present economic crisis (Fig. 1).

The typical features of a holiday home differ from those of a permanent residence, because normally they are only occupied during the holiday season and less time is spent living in the home as the occupants frequently spend their time out of doors. The climate is mild in winter but hot in summer and homes that are lived in permanently need energy resources and building structures, which will provide adequate comfort all year round. In addition to the storage needs of a normal family, they require a larger surface area than the space provided by a holiday home. All these aspects can lead to problems for those who wish to use this type of dwelling as a permanent home, since they were initially designed for use during holiday periods. This situation can be extrapolated to other cities and towns on the Alicante coast, which are also busy tourist resorts such as Torrevieja (51.2\% second homes and $16.3 \%$ empty homes), Gandía (36.5\% second homes and 9.2\% empty homes) or Santa Pola (55\% secondary homes and $13.3 \%$ empty homes), where empty housing is decreasing at a rate of $30 \%$.

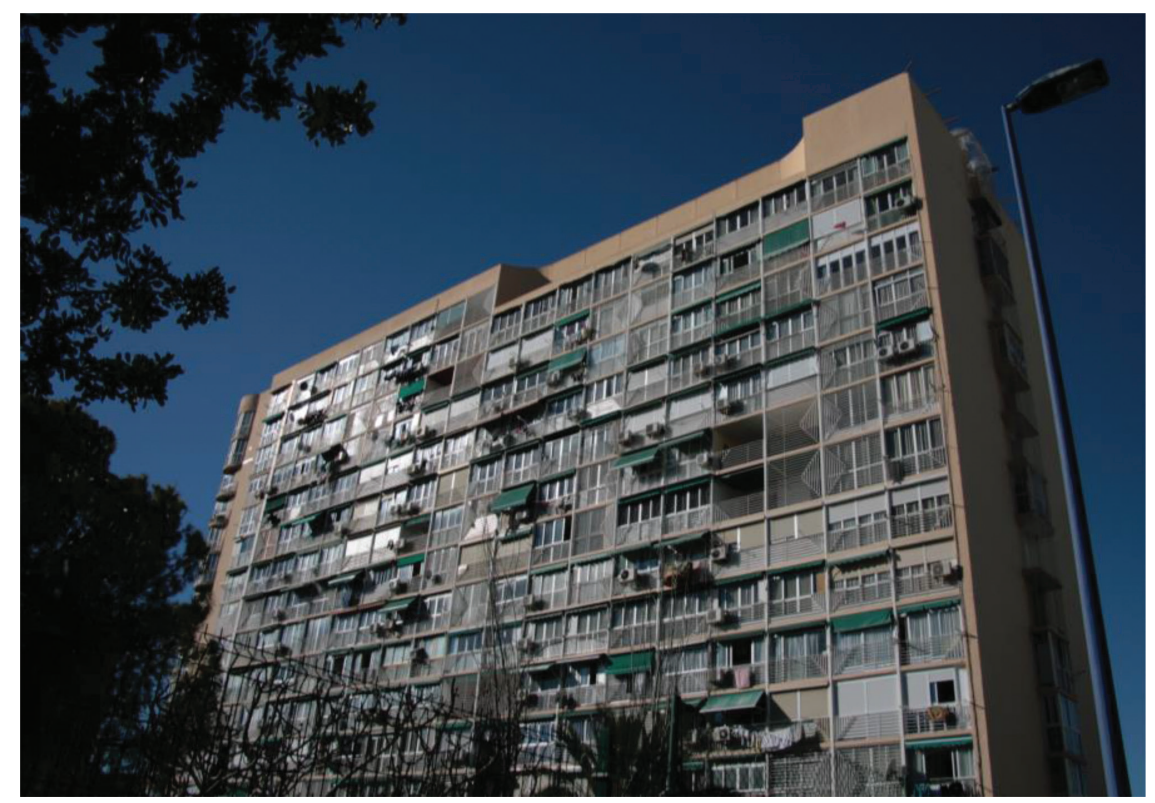

Figure 1: View of the Playmon F complex in Benidorm. 


\section{BENIDORM URBAN CONTEXT}

Benidorm is a town with one of the highest rates of skyscraper per inhabitant in the world and is in fact the second largest in terms of skyscraper per square metre. Thanks to its climate and average temperatures, between $10^{\circ} \mathrm{C}$ in winter and $26^{\circ} \mathrm{C}$ in summer, it is one of Spain's biggest tourist destinations and comes third behind Madrid and Barcelona in numbers of hotel rooms available.

However, Benidorm does not quite fit the concept of tourist resort which began to develop in the nineteen fifties when a real transformation occurred. From an original population of 2,726 inhabitants it rose to 6,259 in 1960 . In 1981, this figure continued to rise to 21,544 inhabitants in 1997 reaching 50,176, and in 2015 the town had 69,010 inhabitants although due to the fact that the majority of foreigners are not registered in the census, it is calculated that around 100,000 inhabitants live there for most of the year. This figure rises sharply when the summer comes, and currently there can be as many as 400,000 inhabitants during the season. Benidorm's growth model contrasts with planning developments in most of the other tourist resorts in the area. Whereas in Torrevieja, Guardamar, Salou, Marina d'Or, etc. most of the accommodation consists of housing estates of low rise two storey terraced houses, in Benidorm the city was planned with considerable height density, creating large areas of public space and rationalising the urban and service infrastructures designed as a model of sustainable planning. The efficiency of travel services, public lighting, refuse collection, waste water evacuation, road maintenance etc. is vastly superior to the models employed by the other municipal districts mentioned above. Its image of high-rise buildings with their authentic skyline, seemingly aggressive in contrast with its coastline and surrounding landscape was criticised at the time by urban planners and architects. Yet now the model has been acknowledged as a success considering the consequences of its uninterrupted growth, and compared to the problems of urban areas that have spread excessively such as Torrevieja which also has 400,000 inhabitants in high season - yet with far more worrying urban and social concerns, and a model of urban growth which is completely inadvisable.

The city's social agents - hotel managers, banks, tourism workers, representatives, renovators and developers etc. perceive the urban landscape and environment as one of Benidorm's greatest plus factors. Nevertheless, it is true that the town is in need of refurbishment as its infrastructures have deteriorated in recent years. Furthermore, its development model may well have reached its peak. Now it proposes to rethink its future, seeking ideas to attract luxury tourism without dispensing with the millions of low cost visitors, and with no real possibility of destroying the stereotype of nineteen sixties tourism. Furthermore, recent existing social problems have been exacerbated and require special attention.

\section{PRESENCE OF SOME SOCIAL CONFLICTS IN BENIDORM}

Chapter 2 of the Ministry of Development's document 'Habitat Spain Agenda: the contribution of cities to sustainable development' [3], identifies various social problems in Spain deriving from the distribution of continuously used second homes and empty housing. In the case of Benidorm, the increased demographic densification, the price of rents and sale of homes, and the need for more services and supplies has exacerbated the living conditions of its inhabitants. It is also worth noting that some buildings are almost like neighbourhoods in themselves, with undesirable overcrowding and this is gradually leading to a rise in social problems [4]. The current serious economic crisis, together with the exorbitant rise in house prices leading up to 2008, meant that families seeking housing moved to homes which had previously only been used for brief summer periods. Thus, sales rose of this type of dwelling, typically with a useful surface area of $30 \mathrm{~m}^{2}$ to $50 \mathrm{~m}^{2}$, due to their extremely reduced prices. 
Another cause of these excessive rates of unused housing, which has led to population movements, is the advanced age of many proprietors of this type of home, built in the nineteen seventies, and their subsequent demise. Another significant cause is the number of evictions carried out by banks for unpaid mortgages as a result of the prolonged economic crisis. And finally, another factor to consider in this redistribution of inhabitants is the increase in 'squatters' occupying homes, a social movement which arose from the precarious situation in which the poorer sectors of society found themselves or those who had been marginalised due to personal circumstances. This situation of living outside the law attracts other activities of the same nature, thus generating a flow between the progressive abandonment of homes and the rise in criminal activities - drugs, alcohol, delinquency - which simply serve to increase the difficult situation of those residents who live in such accommodation on a permanent basis [5]. Thus, an undesirable habitat is created for the younger generation living there, they lack motivation for personal development or for pursuing job opportunities. Clearly, the urban environment needs to be revitalised so that the populace can regain their dignity, and ability for self improvement, while also resolving the social problems that are increasingly arising in these areas.

\section{DESCRIPTION OF THE PLAYMON F BUILDING}

This research focuses on the energy and social rehabilitation of the Playmon $F$ building in Benidorm. The building is 15 storeys high, and almost rectangular in form (Fig. 2). There are 30 homes per floor, with a total of 450 altogether. Each floor has five apartments with a surface area of $60 \mathrm{~m}^{2}$, two with an area of $90 \mathrm{~m}^{2}$ and the rest have a surface area of $30 \mathrm{~m}^{2}$, with a total built surface per floor of $1,200 \mathrm{~m}^{2}$ and extending to $18,000 \mathrm{~m}^{2}$ overall. The $30 \mathrm{~m}^{2}$ apartments face west and the $60 \mathrm{~m}^{2}$ apartments face east. Five homes with an area of $30 \mathrm{~m}^{2}$ face south. The apartments are accessed through a single vertical nucleus, which has five lifts and stairway 1.2 metres wide, which opens inward, leading to an interior hallway. This has no natural light or ventilation and fails to comply with all the normal evacuation regulations in the event of fire and health hazards.

The communal garden is situated to the west of the plot, and accounts for $65 \%$ of the total surface area of the plot, whereas the building only occupies $35 \%$ of the surface. The house fronts are modules $3 \mathrm{~m}$ wide and $2.5 \mathrm{~m}$ high, with a single housing module in the $30 \mathrm{~m}^{2}$ dwellings or two in those with a surface area of $60 \mathrm{~m}^{2}$. They amount to a total of 4,275 $\mathrm{m}^{2}$ of façade of the apartments, a surface which, as we shall see below, will form part of the action to be taken. The construction is simple and of poor quality. The building has a metal structure and the dividing walls of the homes consist of dry partition walls. The outer walls are built from ceramic double airbrick with no thermal insulation and poor quality single layer cement rendering, and the rooms have aluminium frames without thermal break and single glazing.

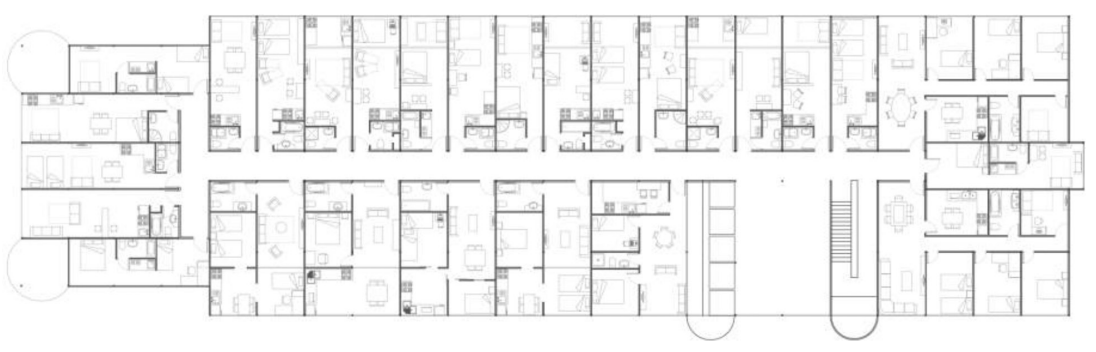

Figure 2: Plan of the Playmon F complex. Current state. 


\section{STRATEGIES FOR SOCIAL AND ENERGY REHABILITATION}

The social problems described above have been encountered in the Playmon F building. In order to alter the trend towards marginalisation in the neighbourhood where the building is located, this research proposes a social and energy rehabilitation programme in terms of ecoarchitecture [6], using the following strategies:

1. Provision of social relations areas on every floor of the building.

2. Increase in the useful surface area of all the homes, duplicating the space in $25 \%$ of the apartments in order to regenerate family life.

3. Construction of a new block of homes in the same plot for rehousing residents during the renovation work and for permanently rehousing 90 families.

4. Provision of a specially protected fire escape staircase.

5. Energy rehabilitation of the building using passive systems and solar collectors with greenhouses on both main façades.

6. The actions will impact as little as possible on the environment and elements of the existing façade will be reused, thus reducing the amount of demolition work required.

\section{MAIN STRATEGY: INCREASED SURFACE AREA + REHOUSING}

Playmon F has 450 homes, 44 of which are empty, cancelled due to eviction or 'squatted'. Our proposal includes dispensing with six homes per floor (four with a surface area of $30 \mathrm{~m}^{2}$ and two with $60 \mathrm{~m}^{2}$ ). If we take into account the second of the strategies this consists of joining some of the $30 \mathrm{~m}^{2}$ apartments to create $60 \mathrm{~m}^{2}$ homes, suitable for housing families with children, which would reduce the number of apartments to 120 (Fig. 3). Where the apartments to be demolished are still occupied, Spanish law provides for protection of its owners and this will be factored into the scope of the action. The Benidorm urban planning model allows for minimum occupation of the plot extension by building at height, providing large areas of green spaces. In order to resolve the problem of rehousing the affected owners, 76 homes would be built within the same original plot. This new construction would consist of a single block of homes, with a surface area similar to that of the existing block with four different heights, covering a total of $4,800 \mathrm{~m}^{2}$ of new building, comprising 50 homes with a surface area of $60 \mathrm{~m}^{2}$, and for 26 with an area of $30 \mathrm{~m}^{2}$. As the buildings are low rise, there would be no shade on the existing building, nor would the view be altered. The $2,500 \mathrm{~m}^{2}$ of garden area would be reduced to $1,200 \mathrm{~m}^{2}$, but there would be clear advantages in the residential quality and for strengthening the residents' identification with the new residential complex.

The demolition phase would result in the need to transfer inhabitants, and therefore new homes would be needed prior to beginning demolition work, in order to avoid extra costs of

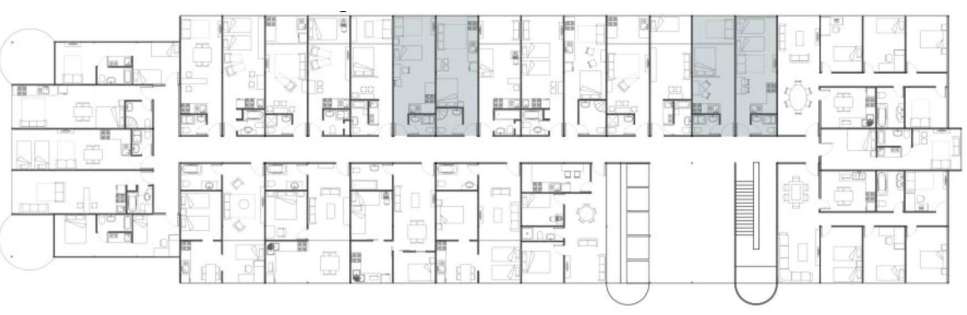

Figure 3: Diagram of the renovation. Social relations areas. 

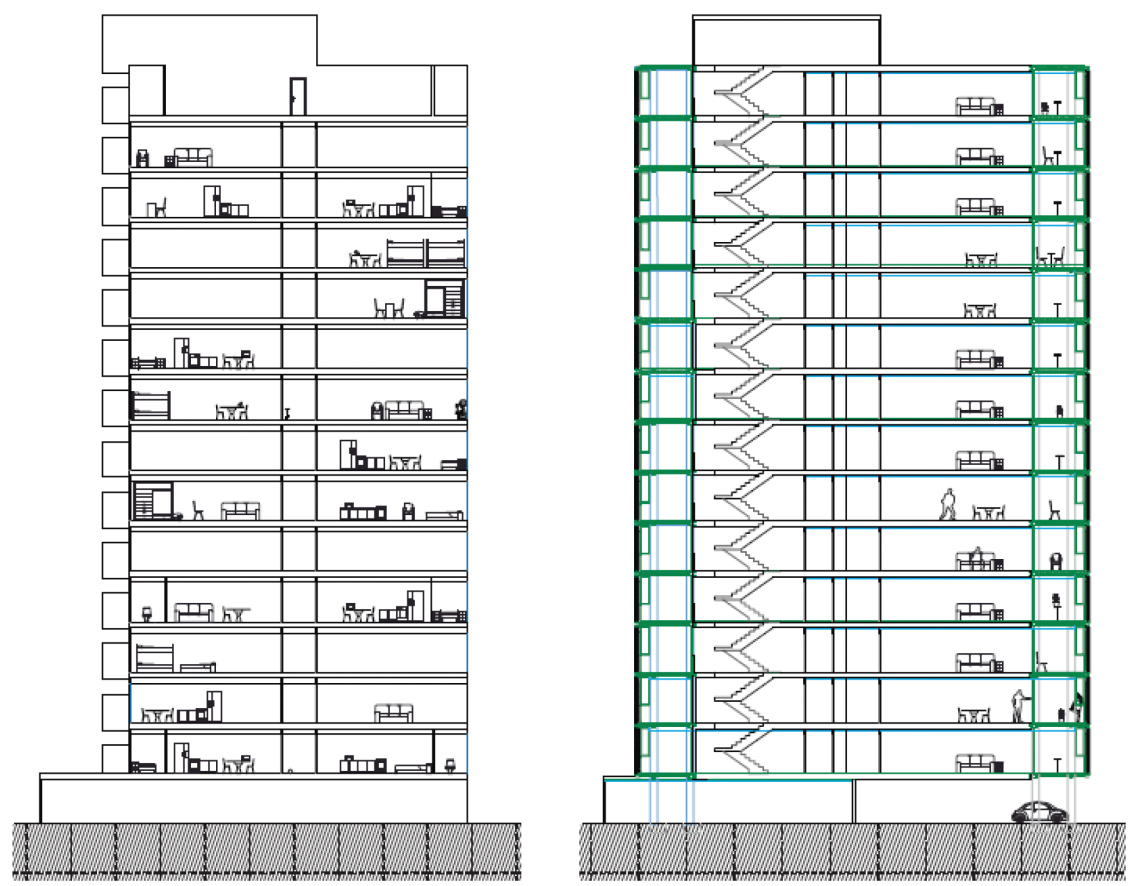

Figure 4: Section of the current state. Application of greenhouses.

temporary housing, and the concomitant inconvenience caused to the residents' lives. Should it prove impossible to build on the same plot, we would need to consider other strategies such as increasing the social housing stock of the city in order to cover the needs of this project. This complicated activity would be simplified with the construction of a new block of homes on the same plot.

\section{ENERGY REHABILITATION: GREENHOUSE AND SOLAR PANELS}

With the previous strategy, the surface area of some of the homes would be increased. In order to achieve this throughout the housing complex while also improving problems of thermal isolation and the high rate of air infiltration in the walls, an external wall would be built 3 metres from the façade based on a metal structure with new foundations, double glazing with chamber and aluminium slats for solar protection creating greenhouses in all the homes (Figs. 4 and 5), using the LCA method [7]. The present interior glass and aluminium enclosure would be kept, and the existing railings would be used. Through correct use of the slats or the opening and closing of the glazed areas, the interior temperatures would be mitigated in both summer and winter. There would also be a variant consisting of the possibility of using photovoltaic cells fitted on the back of the slats to collect solar energy. This would reduce the energy requirements of the homes (Figs. 6 and 7).

Temperature measurements were taken in situ in two of the houses in the complex, in addition to thermographic readings of the outer walls, both inside and outside (Fig. 8). The results obtained showed that the interior environment is far from complying with the level of comfort required under Spanish regulations, namely, the Technical Building Code (CTE). In winter, air temperatures vary between $17^{\circ} \mathrm{C}$ and $19^{\circ} \mathrm{C}$, whereas in summer they frequently reach 

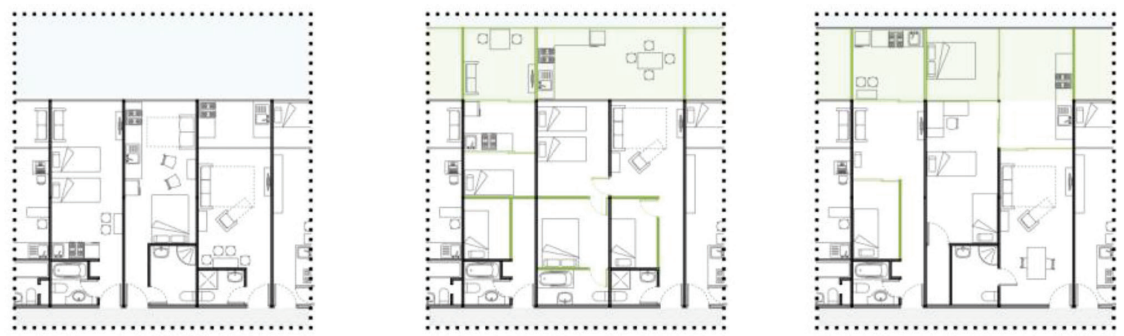

Figure 5: Renovated homes with greenhouses. Types.
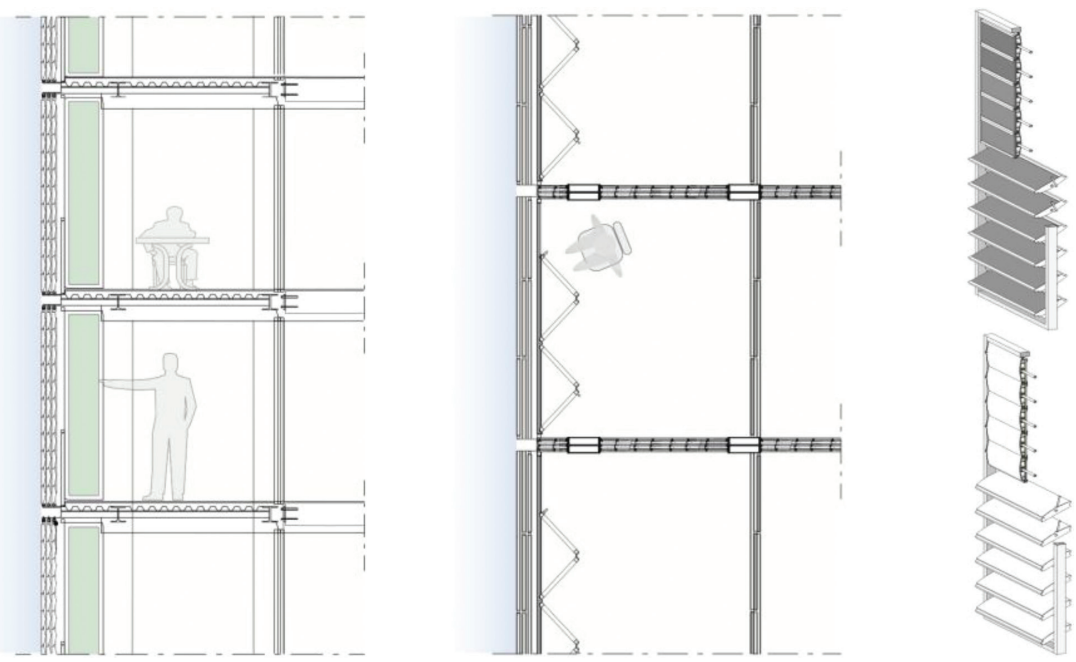

Figure 6: Greenhouses. Adjustable slats and sliding glass doors.

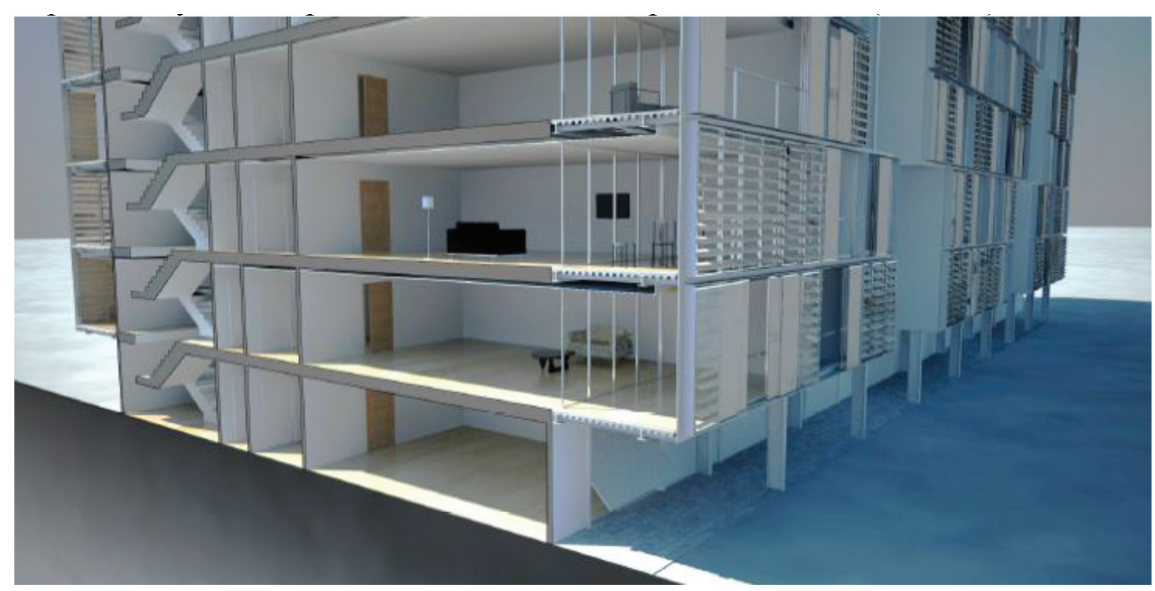

Figure 7: 3D image of the renovation. 


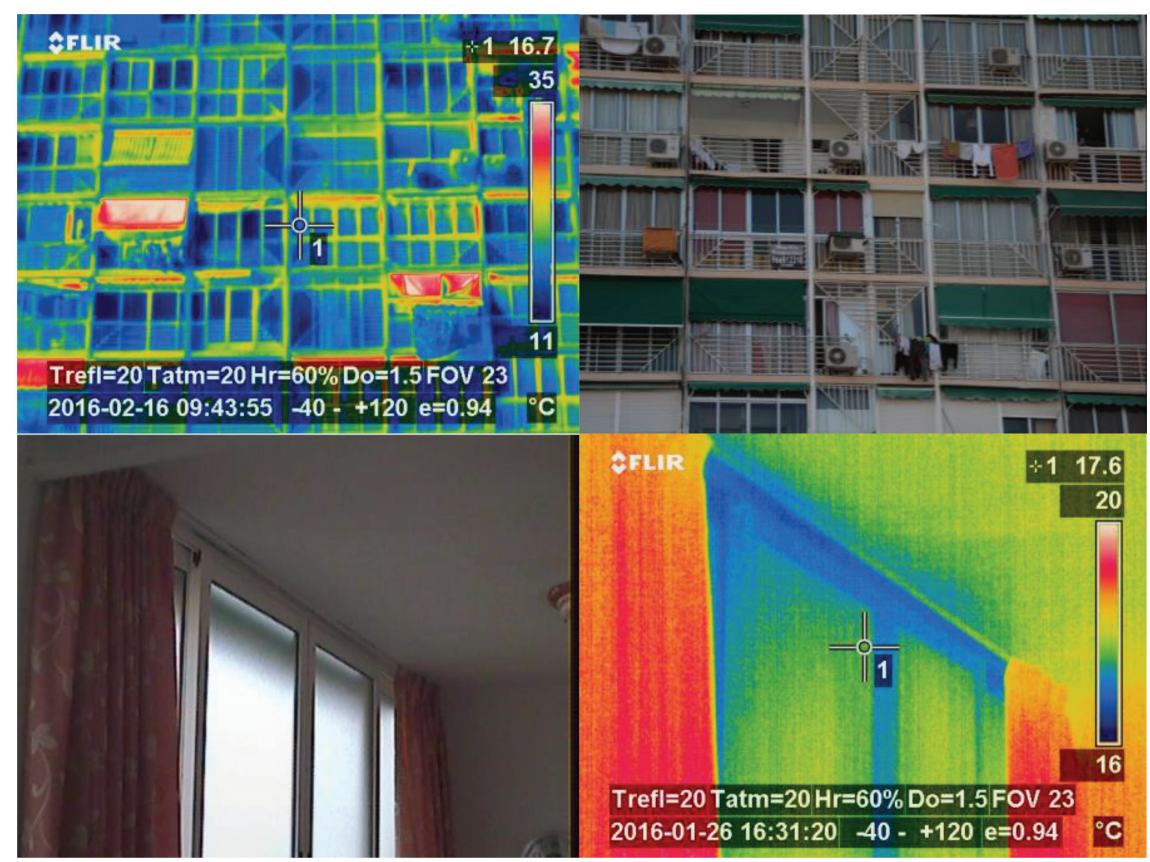

Figure 8: Thermograph of the enclosing walls: inside and outside.

$29^{\circ} \mathrm{C}$ [8]. Only an air conditioning system could keep the home comfortable, thus using considerable energy due to a lack of solar protection and air infiltration in the walls.

With the data obtained, calculations were made by simulating the energy demand of the homes in normal conditions of use, using the Design Builder tool. Following the renovation work, the energy demands of the homes would be halved, and reduced to a quarter in the event of using the more expensive system of photovoltaic cells in the protective slats (Table 1).

\section{COMPLIANCE WITH FIRE REGULATION CTE-DSI}

As explained previously, the Playmon $\mathrm{F}$ has a single vertical communications nucleus, the staircase of which, at a width of 1.2 metres, fails to comply with current regulations specifically CTE-DB-SI3 'Evacuation of occupants'. In addition, access to the apartments is through a dark passageway, with no lighting or ventilation, which is 1.8 metres wide. In order to comply with the CTE-DSI and also to adapt the existing staircase area, it is proposed to install a specially protected staircase in two sections. Furthermore, in order to comply with the distance requirements of the evacuation route at the other side of the building, a block of $30 \mathrm{~m}^{2}$ apartments would be demolished in order to fit a symmetric block of stairs in symmetry with the other staircase, and with the same characteristics. In order to improve the living conditions of the building, it was decided to act on the communal zones, thus complying not only with safety regulations in the event of fire, but also creating more welcoming spaces in which the passageway, instead of being considered a mere transit area to the homes would be seen as an area for interaction of residents as members of a community. The passageways cannot be widened as the useful surface of the homes would be lost, thus they would remain the same width. The areas left by the demolished apartments would be used for communal purposes, enabling the building's residents to interact and get to know each other. In this way 
Table 1: Calculation of the energy requirements of the current state of the building and when reformed.

\begin{tabular}{llll}
\hline & $\begin{array}{l}\text { Current } \\
\text { state }\end{array}$ & PM-1 & $\begin{array}{l}\text { PM-2 } \\
\text { P.SOLARES }\end{array}$ \\
\hline Energy requirements $\mathrm{kWh} / \mathrm{m}^{2} \mathrm{a}$ & 71.5 & 37.3 & 15.4 \\
Annual CO emissions when in use & $143,715 \mathrm{~kg}$ & $74,973 \mathrm{~kg}$ & $30,954 \mathrm{~kg}$ \\
Percentage & $\mathbf{1 0 0 \%}$ & $\mathbf{5 2 . 1 6 \%}$ & $\mathbf{2 1 . 5 3 \%}$ \\
\hline
\end{tabular}

the passageway would become a lighter area with views to the exterior, and it would have natural ventilation, while employing a strategy which would help to resolve social problems and create a sense of identity among the residents.

\section{LIFE CYCLE ASSESSMENT (LCA) AND ENVIRONMENTAL IMPACT}

As a result of implementation of the Directive 2010/31/EU, more energy efficient buildings are required which will have less environmental impact during their use. According to Hernández and Kenny [9], the LCA could be the most appropriate for evaluating environmental and economic impact of buildings from 2018. Recent research has shown how the LCA method can and should be simplified. The extremely complex nature of the method makes it unviable for projects with scant execution budgets or small scale works, and sometimes a considerable number of the impact indicators analysed imply repercussions below the $1 \%$ of environmental impact [10]. For this reason in this research on residential high rise buildings, we propose to focus on impact indicators with a greater environmental impact:

Environmental: creation of construction and demolition waste (CDW), reduction of primary energy and energy demand

Economic: return on investment, life cycle cost analysis

The inventory phase in the life cycle includes all the mass and energy inputs and outputs, emissions, under the same functional unit. The emissions inventory is simplified by entering environmental data from environmental statements, databases or literature [11]. In respect of environmental impact caused by transport of materials, various stages were taken into account such as, for example, transport of materials and solar panels. This was concerned with global energy consumption, GER, and global warming potential GWP.

In order to quantify the emissions in the electricity mix, the ELCD database was taken into account, according to which production of $1 \mathrm{kWh}$ of electricity gives off $0.41 \mathrm{kgCO}, 0.00122$ $\mathrm{kgCH}$ and $0.0000465 \mathrm{kgNO}$ [12]. In order to convert final energy consumption at user point to primary energy consumption and emissions, provisional conversion factors published by IDAE for 2010 were taken into consideration, in particular $2.21 \mathrm{MWh} / \mathrm{MWh}$ and $0.27 \mathrm{tCOeq} /$ MWh respectively. In all the scenarios proposed, efforts have been made to reduce CDW to a minimum (Table 2).

\section{CONCLUSIONS}

As may be seen from the results of Tables 1-3 the costs per home would be just a little more than $9,000 €(\mathrm{PM}-1)$, or 19,000 $€$ in the event of providing solar collector systems (PM-2). These are figures, which we consider could and should be reduced with an appropriate policy of social assistance. With respect to environmental impact, the fact of having renovated the building and having considerably reduced the CDW, and having constructed 76 new built 
130 Urban Regeneration and Sustainability

Table 2: Construction contract costs.

\begin{tabular}{lcccc}
\hline & $\begin{array}{c}\mathbf{m}^{2} \text { or } \\
\text { UD }\end{array}$ & $\begin{array}{c}\text { coste } \\
€ / \mathbf{m}^{2}\end{array}$ & PM-1 & $\begin{array}{c}\text { PM-2 } \\
\text { P.SOLARES }\end{array}$ \\
\hline External metal structure & 12,3 & 350 & $4.205 €$ & $4.205 €$ \\
Aluminium frames + double glazing & 10,5 & 210 & $2.214 €$ & $2.214 €$ \\
Adjustable aluminium slats & 10,5 & 97 & $1.020 €$ & $1.020 €$ \\
Partitions & 8,5 & 62 & $527 €$ & $527 €$ \\
Finishes: paving + plastering+ & 12,3 & 38 & $467 €$ & $467 €$ \\
paintwork & 2 & 120 & $240 €$ & $240 €$ \\
Pine wooden doors & & & $280 €$ & $280 €$ \\
Lighting installations & 12,3 & 870 & $120 €$ & $120 €$ \\
Pre-installation of air conditioning & & & & $10.701 €$ \\
Installation of photovoltaic solar & & & & \\
panels & $\mathbf{1 2 , 3}$ & $\mathbf{7 4 5} €$ & $\mathbf{9 . 1 7 3} €$ & \\
Total PM-1 & $\mathbf{1 2 , 3}$ & $\mathbf{1 . 6 1 5} €$ & & $\mathbf{1 9 . 8 7 4} €$ \\
Total PM-2 & & & $\mathbf{2 . 5 6 8 . 4 4 0}$ & \\
Total 280 apartments west façade & & & & $\mathbf{5 . 5 6 4 . 7 2 0}$ \\
Total 140 apartments east façade & &
\end{tabular}

Table 3: Environmental impact of CDW waste created in the renovation.

\begin{tabular}{|c|c|c|c|c|c|}
\hline \multirow{2}{*}{$\frac{\text { CDW }}{\text { Reinforced concrete }}$} & \multicolumn{2}{|c|}{$\begin{array}{c}\mathbf{S}\left(\mathrm{m}^{2}\right) \\
\text { Unit or } \mathbf{m l}\end{array}$} & \multirow{2}{*}{$\begin{array}{c}\begin{array}{c}\mathbf{m} \\
(\mathrm{Tm})\end{array} \\
37,12\end{array}$} & \multirow{2}{*}{$\begin{array}{c}\begin{array}{c}\text { GER } \\
(\mathrm{MJ})\end{array} \\
193.024\end{array}$} & \multirow{2}{*}{$\begin{array}{c}\begin{array}{c}\mathbf{G W P} \\
\left(\mathrm{kgCO}_{2} \mathrm{eq}\right)\end{array} \\
53.408\end{array}$} \\
\hline & 3,3 & 49,50 & & & \\
\hline Double air brick & 4,1 & 1.845 & 180,66 & 541.980 & 126.462 \\
\hline Cement rendering & 6,3 & 94,5 & 2,916 & 16.038 & 2.770 \\
\hline Plastering & 3,23 & 1.440 & 30,22 & 54.396 & 3.928 \\
\hline Terrazo paving & 3,3 & 49,5 & 3,416 & 17.763 & 3.245 \\
\hline Bonding cement mortar $1: 6$ & 11,8 & 409,5 & 34,41 & 189.255 & 32.689 \\
\hline Ceramic tiles $15 \times 15 \mathrm{~cm}$ & 24,2 & 363,8 & 6,91 & 69.100 & 4.837 \\
\hline Porcelain sanitary appliances & $0,50 \mathrm{Ud}$ & 225 & 5,62 & 64.630 & 5.339 \\
\hline Copper piping average $\varnothing 12 \mathrm{~mm}$. & $0,6 \mathrm{ml}$ & 220 & 0,226 & 14.220 & 1.769 \\
\hline PVC piping average $\varnothing 40 \mathrm{~mm}$ & $0,8 \mathrm{ml}$ & 265 & 0,203 & 14.210 & 2.109 \\
\hline TOTAL & & & & 1.174.616 & 236.556 \\
\hline
\end{tabular}

homes, energy would have been reduced by $70 \%$ compared to $100 \%$ of a new build system. In addition, the reduction in energy demand is extremely significant $-48.84 \%$ for PM- 1 and $78.47 \%$ for PM-2 - with a substantial improvement in comfort. It is clear that the reduction of social problems through these actions would improve the quality of life and social relations between neighbours, and result in cost savings in areas such as health and safety, 
education or energy. These measures are therefore necessary and viable for the urban regeneration of Benidorm and its incipient social problems and they are also applicable to other similar tourist destinations.

\section{REFERENCES}

[1] Rogers, R. \& Gumuchdjian, P., Cities for a Smalll Planet, Faber \& Faber Limited: London, p. 3, 1997.

[2] Population and Housing Census 2011 Buidlings and homes. Provisional data [on line]. National Statistics Institute, 2013.

[3] Agenda Habitat España: contribución de las ciudades al desarrollo sostenible [on line]. Ministerio de Fomento, 1997. [search: 28 february 2016], Available at: http://habitat. aq.upm.es/aghab/aghabes.html

[4] Fraile, P., Represión y conflicto en la sociedad globalizada. Scripta Nova, 12, 2008.

[5] Glick Schiller, N. \& Schmidt, G., Envisioning place: urban sociabilities within time, space and multiscalar power. Identities, 23(1), pp. 1-16, 2016. http://dx.doi.org/10.1080/1070289X.2015.1016524

[6] Yeang, K., Ecodesign. A Manual for Ecological Design, John Wiley \& Sons, Ltd: London, p. 415, 2006.

[7] Assiego, R., Calleja, G., Cejudo, J.M., Raugei, M. \& Palmer, P.F.I., A decission-making LCA for energy refurbishment of buildings. Conditions of comfort. Energy and Builidngs, 70, pp. 333-342, 2014. http://dx.doi.org/10.1016/j.enbuild.2013.11.049

[8] Forgiarini, R., Giraldo, N. \& Lamberts, R., A review of human thermal comfort in the built environment [on line]. Energy and Buildings, 105(15), pp. 178-205, 2015.

[9] Hernández, P. \& Kenny, P., From net energy to zero energy buildings: Defining life cycle zero energy and buildings (LC-ZEB). Energy \& Buildings, 42, pp. 815-821, 2010. http://dx.doi.org/10.1016/j.enbuild.2009.12.001

[10] Oregi, X., Hernández, P., Gazulla, C. \& Isasa, M., Integrating simplified and full life cycle approaches in decisión making for building energy refurbishment: benefits \& barriers. Buildings, 5(2), pp. 354-380, 2015. http://dx.doi.org/10.3390/buildings5020354

[11] Swiss Centre for Life Cycle Inventories, Ecoivent 3, Available at: https://ecoquery.ecoivent.org/File/Reports

[12] ELCD Database, Available at: www.eplca.jcr.ec.europa.eu/ELCD3/index.xhtml;jsession id=9FC03F3B6A0A5F8252F667E462DF467C 